2. Ефимов А.В., Минервин Г.В., Ермолаев А.П., Шимко В.Т., Щептиков Н.И., Гаврилина А.А., Кудряшев Н.К. Дизайн архитектурной среды: учебник для вузов. М.: Архитектура - С, 2006. 504 с.

3. Пилипчук О.Д., Полубок А.П. Рішення творчого задуму художньо-декоративної форми в залежності від застосованих матеріалів // ScienceRise. DOI: https://doi.org/10.15587/2313-8416.2019.164772

4. Техническая эстетика и дизайн: словарь под общей ред. М.М. Калиничевой. М.: Академический проект: Культура, 2012. 356 с.

DOI https://doi.org/10.30525/978-9934-26-004-9-71

\title{
ТВОРЧІСТЬ ЯК ФОРМА САМОБУДІВНИЦТВА ОСОБИСТОСТІ
}

\author{
Шлемкевич С. Л. \\ кандидат філософських наук, доцент, \\ дочент кафедри філософії, соціології та культурології \\ Національного лісотехнічного університету України \\ м. Львів, Украӥна
}

Реалії сучасного світу викликають динамічні зміни у всіх сферах людської діяльності, актуалізують пошуки нових нетрадиційних шляхів формування та розвитку особистості, яка повинна бути готовою змінюватися, оволодівати новими професіями, ставати більш мобільною у прийнятті рішень. Якщо в минулому цілком виправданим вважалося уявлення щодо процесу формування особистості як процесу накопичення певної сукупності знань та навичок, які забезпечать повноцінне функціонування людини як фахівця-спеціаліста, то сьогодні уявлення про всебічно розвинуту особистість, перш за все, асоціюється із установкою на креативність, на здатність реалізувати творчий потенціал і у цьому вищому злеті творчої енергії втілити всю багатогранність і повноту життя, дарованого Богом, долею, часом. При цьому сутнісним результатом процесу творчості виступає не стільки нова якість дії, скільки ускладнення самого духовного вияву буття, його нові виміри.

Розуміння творчості як сутнісної характеристики людини, як особливої форми вияву духовності, дає можливість вважати творчою не тільки діяльність, що завершується продукуванням «нового», а й таку, головною сферою якої $є$ формування людських якостей, ускладнення культурного і духовного потенціалу особистості, залучення до вищих смислів Буття. Таке трактування певною мірою вступає у протиріччя 3 
традиційним осмисленням творчості. Однак, протиріччя це знімається, якщо нагадати, що філософське осмислення феномену творчості знаходиться у безпосередньому зв'язку з процесом культурного розвитку людства, узгоджується 3 відповідними етапами розвитку духовної культури. У добу античності все, зроблене людиною, мислилось лише недовершеним відбитком Космічної доцільності. При цьому міра досконалості трактувалася не як вияв авторської індивідуальності, а як продукт надіндивідуального, в якому відкарбувалася здатність почути поклик «божественного голосу». Своєрідне осмислення дійсності, коли будь-які зміни на шляху з «вчора» у «сьогодні» могло трактуватися як віддзеркалення особливої реальності (Логосу, світу ідей), виключало можливість протиставлення «творчого й нетворчого». Отож для античного мислителя виділення творчості в особливу сферу дослідження було просто недоцільним.

У середньовіччі кульмінацією творчої діяльності визнавалася мить благодаті, що дарована Богом за відповідні дії.

Інтенція на особу, що вільно окреслює сценарій свого існування, проявилася у добу Відродження у типі «ренесансової» людини. В самосвідомості цієї епохи утверджувалася ідея активності та самостійності суб'єкта, його здатності до діяльнісного та критичного ставлення до світу. Творчість осмислювалася як пошукова діяльність, спрямована назовні. Атрибутом творчості визнавалося створення нового, небувалого, а сама природа почала асоціюватися з образом майстерні, в якій людина може дозволити собі конструювати нові форми.

У подальшому творчість все більше пов'язувалася 3 набуванням навичок технологічного освоєння безмежних просторів реальності. Таке розуміння творчості та її суб'єкта - людини як хазяїна буття, у наступних історичних епохах призвело до досить складних колізій екологічного та морального звучання, наслідки яких спостерігаємо сьогодні повною мірою. Можливо, саме ця обставина обумовила необхідність у сучасній філософській практиці грунтовно осмислити ті аспекти творчого процесу, які пов'язані, перш за все, 3 самобудівництвом і самореалізацією особистості.

Творчість не може вважатися привілеєм елітарної меншості, а виступає як сутнісне визначення особистості. Таке розуміння достатньо повно виявляє характер перемін, які відбуваються у сучасному світі та може слугувати ключем до визначення змісту поняття «творча особистість», яке не отримало ще достатнього філософського обгрунтування і використовується найчастіше як поетична метафора. Творча особистість, керуючись у своїй діяльності свідомо-вольовими 
орієнтирами та гарантованим ступенем корисності, у процесі творчості транслює своє «Я» у світ, втілюючи у життя універсальне покликання людини щодо відтворення та збагачення світу культури.

При цьому необхідно зазначити, що конкретна особистість обирає для себе ціннісні орієнтації, звертаючись до духовного арсеналу минулого. А відтак, для гармонійного розвитку особистості цілком недостатньо здійснити чисто «механічне» (формальне, поверхневе) ознайомлення 3 культурним надбанням людства, необхідно сформувати самостійну компетентну оцінку тих чи інших фрагментів культури. При цьому «творчість не межує з потенційністю, а визначається нею як вивільнення 3 обіймів ніщо. При всій обумовленості творчості попередньою традицією, вона починається з такого їі засвоєння, коли попередній досвід вбирається, «знімається» новим матеріалом чи задумом творця, виявляючи потенційну сферу того, що народжується» [1, с.52].

Власне, базовим «полем випробування» такої поведінки повинна стати вища школа, яка має всі можливості для гармонізації розвитку індивідуально-своєрідних рис особистості та соціально набутого досвіду. Сьогодні в Україні широко обговорюються проблеми реформування системи освіти, зокрема i у вищій школі. Особливої ваги набирають питання, пов'язані 3 визначенням місця гуманітарних дисциплін в освітньо-виховному процесі. Адже саме ці дисципліни зорієнтовані на формування світогляду, нестандартних способів діяльності, універсально творчого сприйняття дійсності. Саме вони дають можливість удосконалювати механізми ведення дискусій, формулювати завдання, що покликані розвивати уяву, оптимізувати творчий пошук, широко використовувати проблемні методи навчання, за яких заперечується банальна форма спілкування викладача та студента на рівні «питаннявідповідь». Важливо і те, що гуманітарні дисципліни, особливо курси історії України, історії української культури, історії мистецтва забезпечують процес безпосереднього опанування цінностями культури, формування власних, непересічних поглядів особистості.

Дисципліни, пов'язані 3 теоретичним та практичним освоєнням надбань у сфері художньої творчості, займають особливе місце серед інших, Дисципліна «Історія мистецтва та архітектури» $є$ обов'язковою для студентів, що навчаються у мистецьких ВНЗ України, але ще донедавна до вивчення цієї дисципліни залучалися й студенти інших напрямків. На жаль, така практика стосовно історії мистецтва більшості вищих навчальних закладів України не підтримується. Все менше навчальних годин виділяється i на вивчення інших гуманітарних дисциплін, особливо у навчальних закладах технічного спрямування. 
Прикро. Адже вивчаючи історію розвитку культури, усвідомлюючи зміст основних мистецтвознавчих категорій, студенти змогли б навчитися оцінювати значення для цивілізації, культури людства художньої творчості видатних митців, підвищити суб'єктивну культуру сприйняття творів мистецтва, розвинути естетичний смак, навчитися прогнозувати спрямованість майбутніх культурних процесів. Зрештою, сформувати таку систему культурних орієнтацій та установок особистості, яка б утверджувала пріоритет загальнолюдських цінностей та гуманітарний розвій культури.

Творити життя за законами краси! Чи не таке гасло воліли б ми сьогодні проголосити як визначальне у формуванні всебічно розвинутої творчої особистості, якій до снаги взяти відповідальність за майбутне своєї Батьківщини й людства загалом.

\title{
Література:
}

1. Кримський С. Запити філософських смислів. К.: ПАРАПАН, 2003. $240 \mathrm{c}$.

DOI https://doi.org/10.30525/978-9934-26-004-9-72

\section{BEADING THE WOMANTORY: ART PROJECT AS A WAY TO TELL ABOUT WOMEN'S HISTORY}

\author{
Shcherbina M. M. \\ Ph.D. in Philosophy of Culture, Associated Professor, \\ Associated Professor at the Philosophy Department \\ Kharkiv National Medical University \\ Kharkiv, Ukraine
}

History and mythology are the binder that brings us together, the base for dignity and self-respect. However, women's history often remains hidden from ordinary people. Ukrainian historian Martha Bogachevskaya-Khomyak compared the history of women with traditional embroidery in white and white: the metaphor is sad but true. The purpose of the project for the unique Ukrainian Gendermuseum (the Museim of Women's and Gender History - the creator and director of the museum is Tatiana Isaeva, the author and coordinator of the project is Maria Shcherbina) was a new option to reveal and show the world white faces of women - scientists, artists, human rights activists, writers, 